\title{
A COMPARATIVE STUDY OF EFFICACY OF CENTCHROMAN AND EVENING PRIMROSE OIL IN TREATMENT OF BENIGN BREAST DISEASE
}

\author{
Sreeja Biswas Roy1, Rasbihari Hembram²
}

1MD, Department of General Surgery, St. Joseph's Hospital and Medical Centre, Phoenix, Arizona.

${ }^{2}$ Assistant Professor, Department of General Surgery, College of Medicine and JNM Hospital, Kalyani, West Bengal, India.

ABSTRACT
BACKGROUND
Fibroadenomas are the most common breast lumps in women younger than 30 yrs. of age and the most common solid tumours in
breast of women of all ages with a peak incidence at around 20 yrs. of age. Hormonal therapy of fibroadenomas is the common
mode of treatment and tamoxifen reduces volume of fibroadenomas by around $20 \%$. Centchroman is a non-steroidal, selective
anti-oestrogen and has the advantages of less frequent administration and is free from side effects of steroidal agents. It has an
excellent safety profile even in lactating women. It is free from teratogenic, mutagenic or carcinogenic side effects. Centchroman
elicits weak oestrogenic agonistic and potent antagonistic activities, but is devoid of progestational, androgenic and anti-
androgenic properties.
The aim of the study is to compare the efficacy of Centchroman and Evening Primrose oil in treating breast pain with or
without nodularity in patients with fibrocystic disease and regression of smaller fibroadenomas $(<4 \mathrm{~cm})$.

\section{MATERIALS AND METHODS}

This longitudinal study was conducted in Department of General Surgery and included female patients aged 16 - 35 yrs. presenting to outpatient department, suffering from benign breast disease. The study was conducted from June 2017 to May 2018 and included 140 patients, 82 in Centchroman group and 58 in EPO group.

\section{RESULTS}

Majority of the patients in Centhroman group (84\%) responded excellently compared to EPO (Evening Primrose Oil) group (25\%) with respect mastalgia. Nodularity decreased in $80 \%$ of patients in Centchroman arm and $26 \%$ in EPO arm. Complete response to treatment of fibroadenoma was noted in $40 \%$ of patients with Centchroman treatment, while only a dismal of $6 \%$ (1 patient) showed response to EPO treatment.

\section{CONCLUSION}

Most patients with benign breast disease present in the third decade of life. The most common symptom in patients with benign breast disease is mastalgia followed by tender nodularity of breasts. Centchroman is significantly better than Evening Primrose Oil (EPO) in causing regression of breast lumps in fibroadenomas, in causing relief from breast pain in benign breast disease and in regression of tender nodularity in patients of fibrocystic disease of the breast. Both Centchroman and EPO have excellent safety and side effect profile with no serious adverse effects reported in either of the treatment groups.

\section{KEY WORDS}

Benign Breast Disease, Fibroadenoma, Fibrocystic Disease, Centchroman, Evening Primrose Oil.

HOW TO CITE THIS ARTICLE: Roy SB, Hembram R. A comparative study of efficacy of centchroman and evening primrose oil in treatment of benign breast disease. J. Evolution Med. Dent. Sci. 2018;7(31):3518-3524, DOI: 10.14260/jemds/2018/791

\section{BACKGROUND}

The vast majority of lesions which occur in the breast are benign. ${ }^{1}$ Previously mastalgia was regarded as a trivial symptom, but careful clinical study by Preece Mansel and Hughes has shown that it is not seen only in 'neurotic patients.'2 Furthermore, several forms of mastalgia can be distinguished from clinical history. ${ }^{3}$ Some widely used drug treatments for mastalgia have been discarded such as diuretics have often been used to counteract supposed water retention, but isotopic measurements of changes in total body

'Financial or Other Competing Interest': None.

Submission 13-07-2018, Peer Review 25-07-2018,

Acceptance 27-07-2018, Published 30-07-2018.

Corresponding Author:

Dr. Rasbihari Hembram,

Assistant Professor

Department of General Surgery,

College of Medicine and JNM Hospital,

Kalyani, Nadia-741235, West Bengal, India.

E-mail: pratheek.n2012@gmail.com

DOI: $10.14260 /$ jemds $/ 2018 / 791$ water showed no differences between controls and patients with breast pain. 4

Three hormonal theories emerged regarding aetiology of painful nodular breasts: increased oestrogen secretion from ovary, deficient progesterone production (relative hyperoestrogenaemia) and hyperprolactinaemia. One study of sampling of prolactin at a fixed time throughout the menstrual cycle showed a small but statistically significant difference between women with cystic pain and controls. ${ }^{5}$ Petes and colleagues showed that the stimulated prolactin response to Thyrotropin Releasing Hormone (TRH) was greater in patients with mastalgia than controls. ${ }^{6}$

There seems to be a role of oestrogen receptor status in the pathogenesis of benign breast disease. Patients with ERpositive breast disease responded better to danazol than patients with ER-negative breast disease in a study conducted by Khanna and colleagues. ${ }^{7}$

Abnormal prostaglandin synthesis has also been implicated in the aetiology of mastalgia. Gateley et al measured the plasma fatty acid levels in patients with mastalgia and found that they have increased saturated fatty 
acids and reduced EFAs. ${ }^{8}$ EFA deficiency accentuated prolactin effects on breast cells, because of deficient production of PGE 1. Elevated HDL-C has been reported in patients with cyclical mastalgia, but not in those with noncyclical pain. ${ }^{9}$ That only cyclical forms of mastalgia respond to hormonal therapy seems to be a myth, as non-cyclical mastalgia when properly differentiated from musculoskeletal pain shows better response to hormonal therapy than previously thought. ${ }^{10}$

A number of dietary therapies have been tried, but on subsequent randomised trials have failed to demonstrate a clear advantage in treatment of mastalgia.11-13 Oral contraceptives have shown to be protective in benign breast disorders. ${ }^{14}$ Topical NSAIDS have also been used to some effects.

Efficacy of Evening Primrose Oil in benign breast disease was shown in older studies. ${ }^{15}$ However, in a recent randomised, double-blind control trial conducted by Blommers and colleagues in 2002, premenopausal women in severe chronic mastalgia were placed in four groups for six months: (1) Fish oil and control oil, (2) EPO and control oil, (3) Fish oil and EPO and (4) Both control oils. In this study, neither EPO nor fish oil offered clear benefit over control in treatment of mastalgia. ${ }^{16}$

Low levels of the metabolite Gamolenic Acid (GLA) an essential Polyunsaturated Fatty Acid (PUFA) have been identified in the plasma of women with cyclical mastalgia. A Cardiff study in 2005, randomised patients into four groups: (1) GLA and antioxidants, (2) Placebo and antioxidants, (3) GLA and placebo and (4) Placebo and fatty acids. The investigators concluded that GLA efficacy did not differ from placebo regardless of whether anti-oxidant vitamins were present.

In 1971, Greenblatt and colleagues, while treating patients with endometriosis observed improvement of breast symptoms in women. ${ }^{17}$ Further reports from the same group described the use of danazol in dosages from 100 to $400 \mathrm{mg}$ per day for $3-6$ months in over 300 women with varying types of benign breast disease and reported total resolution of pain and nodularity in about $80 \%$ of patients. In the west, the recommendation is to use a maintenance dose of $100 \mathrm{gm}$ daily on alternate days. Danazol is superior to bromocriptine in the treatment of cyclical breast pain. ${ }^{18}$

Bromocriptine has shown an overall response rate of $75 \%$ in two separate double-blind studies. ${ }^{19,20}$ Side effects were noted in $40 \%$ of the cases, severe enough to cause drop out of $17 \%$ of patients in one trial. The cyclical pattern of pain is significantly reduced in bromocriptine when compared with placebo. ${ }^{20}$

In a double-blind study, $10 \mathrm{mg}$ daily dose of tamoxifen significantly improved mastalgia with response rates of $98 \%$ for cyclical and $56 \%$ for non-cyclical pain. ${ }^{21}$ Side effects were reported to be minimal. Extending treatment beyond 3 months did not increase response rate nor did it reduce the relapse rate.

In a large randomised multicentre study for the treatment of mastalgia, goserelin (LHRH analog) has shown effect as short-term treatment. ${ }^{22}$ However, because side effects are common, it is reserved for patients whose pain is refractory to other treatment modalities.

Fibroadenomas are the most common breast lumps in women younger than 30 yrs. of age and the most common solid tumours in breast of women of all ages with a peak incidence at around 20 yrs. of age. ${ }^{23}$ Dent and Cant showed that $30 \%$ of fibroadenomas undergo complete disappearance over a period of 24 months without treatment. ${ }^{24}$

Hormonal treatment of fibroadenomas has been suggested by some. Viviani evaluated the sonographic volume of fibroadenomas in pre-menopausal women treated with tamoxifen for 50 days and concluded that tamoxifen reduces volume of fibroadenomas by around $20 \%$ at the dose of 20 mg per day. ${ }^{25}$

Centchroman elicits weak oestrogenic agonistic and potent antagonistic activities but is devoid of progestational, androgenic and anti-androgenic properties. ${ }^{26-28}$ An early return to fertility after stopping therapy makes it safe in the treatment of unmarried women and those who wish to conceive after treatment. Women who conceived while on treatment gave birth to healthy children in the phase 3 contraceptive trials that have been going on.

A pilot study conducted by Dhar and Srivastava in AIIMS showed that Centchroman caused complete disappearance of breast pain and nodularity in almost all patients at the end of 1 month of treatment. ${ }^{29}$ The fibroadenoma group showed mixed response (40\% complete disappearance, $20 \%$ partial disappearance and the rest $40 \%$ no response). ${ }^{30,31}$

Multiple treatments have been used in women with benign breast disease, whose cause as well as treatment have been a topic of research. ${ }^{32}$ Careful clinical study has shown that 'neuroticism' is not a major factor for mastalgia in benign breast disease and that several patterns of breast pain can be distinguished from clinical history. Two durable theories of relative hyperoestrogenism and hyperprolactinaemia have given impetus to the hormonal treatments for benign breast disease. The commonly used agent evening primrose oil has shown to be useful in treating cyclical mastalgia in benign breast disease, but its efficacy is still in debate. Antihormonal agents like danazol, bromocriptine, tamoxifen and LHRH analogs have been used, but most of them are steroid-based with significant side effects. ${ }^{32-35}$

Centchroman is a non-steroidal, selective anti-oestrogen synthesised in CDRI, Lucknow. It has the advantages of less frequent administration and is free from side effects of steroidal agents. It has an excellent safety profile even in lactating women. It is free from teratogenic, mutagenic or carcinogenic side effects, does not affect the HPO axis and does not alter blood sugar or lipid profiles. At twice or thrice weekly dosages, it maintains normal ovulatory cycles. The contraceptive action is readily reversible and subsequent pregnancy outcome is normal. Some studies have shown its efficacy in treatment of benign breast diseases, specifically mastalgia and fibroadenoma. ${ }^{35-38}$

Though, it has been proven time and again that hormonal therapy is effective in mastalgia, EPO still forms the mainstay of treatment in patients suffering from tender nodularity and mastalgia due to benign breast disease, thus entailing a huge economic burden to the already limited resources in the state. Furthermore, recent times have seen a shift from surgery to conservative management of simple fibroadenomas in women younger than 35 years as they have a benign course. ${ }^{38}$ This study aims to find a more effective, yet cheaper alternative to treat benign breast disease in these two groups of patients. 


\section{Aims and Objectives}

1. To compare the efficacy of Centchroman and Evening Primrose oil in treating breast pain with or without nodularity in patients with fibrocystic disease.

2. To compare the efficacy of Centchroman and Evening Primrose oil in regression of smaller fibroadenomas $(<4 \mathrm{~cm})$.

\section{MATERIALS AND METHODS}

This longitudinal study was conducted in Department of General Surgery and included female patients aged 16 - 35 yrs. presenting to outpatient department suffering from benign breast disease. The study was conducted from June 2017 to May 2018 and included 140 patients, 82 in Centchroman group and 58 in EPO group.

\section{Sample Design}

All female patients aged 16 - 35 years with history of benign breast disease were included in the study. Patients with a history of breast pain with or without tender nodularity and cases of fibroadenoma $<1=4 \mathrm{~cm}$ in size, after triple assessment (clinical exam, USG, FNAC) were included in this study.

\section{Study Design}

Longitudinal study.

\section{Sample Size}

During the study period, all the subjects meeting the inclusion criteria and taking either centchroman or evening primrose oil as the main modality of treatment were enrolled into the study.

\section{Allocation Method}

Since this is a longitudinal observation study, those individuals who were put on treatment either with centchroman or evening primrose oil by the treating surgeon were included into the study.

\section{Parameters to be Studied}

Clinical Response was the main Outcome of Interest. The following Clinical Parameters were studied-

1. Mastalgia- Recorded as severity score (Breast Cardiff Score 0 - 4).

2. Nodularity- Recorded by palpation and coded as complete or partial remission.

3. Fibroadenoma- Size recorded clinically and radiologically.

\section{Study Technique}

All patients had a clinical breast examination and ultrasound of breast. Breast pain score was recorded according to Cardiff score (BCS) from 0 to 3 . The size of the breast lump was recorded. FNAC was done in fibroadenomas and palpable nodularity of the breast. Sexually active women underwent an additional gynaecologic evaluation and ultrasound of the pelvis to rule out polycystic ovarian disease.

All patients in the Centchroman group were given 30 milligrams alternate day for 3 months and those in the evening Primrose oil group were given 1000 milligrams daily for 3 months. Clinical reassessment was done at the end of 2 weeks, 4 weeks, 3 months and 6 months follow-up. Radiologic breast re-evaluation was done at the end of 1 month, 3 months and 6 months. All data were analysed following standard statistical protocol.

Statistical Method: Data was summarised by frequency and proportion for qualitative data and mean and standard deviation for quantitative data. The difference in reduction of pain at the end of the study between centchroman and evening primrose oil group was compared using chi-square test. For statistical analysis, SPSS software version 25 was used.

\section{RESULTS}

1. Age

\begin{tabular}{|c|c|c|c|c|c|c|}
\hline \multirow[t]{2}{*}{ Groups } & \multirow[t]{2}{*}{ Disease } & \multicolumn{4}{|c|}{$\begin{array}{c}\text { Groups Disease Age Groups } \\
\text { (yrs.) }\end{array}$} & \multirow[b]{2}{*}{ Total } \\
\hline & & $16-20$ & 21-25 & $26-30$ & 31-35 & \\
\hline \multirow{2}{*}{ Cen } & FA & $\begin{array}{c}2 \\
(2.4)\end{array}$ & $\begin{array}{c}11 \\
(13.4)\end{array}$ & $\begin{array}{c}4 \\
(4.9)\end{array}$ & $6(7.3)$ & $\begin{array}{c}23 \\
(28)\end{array}$ \\
\hline & FC & $\begin{array}{c}9 \\
(11)\end{array}$ & $\begin{array}{c}20 \\
(24.4)\end{array}$ & $\begin{array}{c}22 \\
(26.8)\end{array}$ & $\begin{array}{c}8 \\
(10)\end{array}$ & $\begin{array}{l}59 \\
(72)\end{array}$ \\
\hline \multirow{4}{*}{ EPO } & Total & $\begin{array}{c}11 \\
(13.4)\end{array}$ & $\begin{array}{c}31 \\
(37.8)\end{array}$ & $\begin{array}{c}26 \\
(31.7)\end{array}$ & $\begin{array}{c}14 \\
(17.1)\end{array}$ & $\begin{array}{c}82 \\
(100)\end{array}$ \\
\hline & FA & $\begin{array}{c}1 \\
(1.7)\end{array}$ & $\begin{array}{c}6 \\
(10.3)\end{array}$ & $\begin{array}{c}7 \\
(12.1)\end{array}$ & $\begin{array}{c}3 \\
(5.2)\end{array}$ & $\begin{array}{c}17 \\
(29.3)\end{array}$ \\
\hline & $\mathrm{FC}$ & $\begin{array}{c}5 \\
(8.6)\end{array}$ & $\begin{array}{c}17 \\
(29.3)\end{array}$ & $\begin{array}{c}12 \\
(20.7)\end{array}$ & $\begin{array}{c}7 \\
(12.1)\end{array}$ & $\begin{array}{c}41 \\
(70.7)\end{array}$ \\
\hline & Total & $\begin{array}{c}6 \\
(10.3)\end{array}$ & $\begin{array}{c}23 \\
(39.6)\end{array}$ & $\begin{array}{c}19 \\
(32.8)\end{array}$ & $\begin{array}{c}10 \\
(17.2)\end{array}$ & $\begin{array}{c}58 \\
(100)\end{array}$ \\
\hline \multicolumn{7}{|c|}{$\begin{array}{c}\text { Table 1. Number and Percentage distribution of patients } \\
\text { by their age of presentation with respect to Disease and } \\
\text { Treatment (Total No. of Patients= 140) }\end{array}$} \\
\hline
\end{tabular}

Note: Figures in brackets are in percentages.

The above table shows that there was a slight difference in age distribution of patients in the Centchroman and EPO groups with respect to disease. While fibroadenoma was the most common in 21 - 25 years' age group in the Centchroman arm, the 26 - 30 years' age group showed highest percentage of patients in the EPO arm. However, the reverse was true for fibrocystic disease. It was noteworthy that overall, benign breast disease was most common in the 21 - 25 years' age group in both the EPO and Centchroman arms.

\begin{tabular}{|c|c|c|c|}
\hline \multirow[t]{2}{*}{ Groups } & \multicolumn{2}{|c|}{$\begin{array}{c}\text { Disease } \\
\text { (Mean Age }+/- \text { SD) Total }\end{array}$} & \multirow[t]{2}{*}{ Total } \\
\hline & FA & FC & \\
\hline Cen & $26.0+/-4.6$ & $25.5+/-4.7$ & $25.62--4.65$ \\
\hline EPO & $26.1+/-4.6$ & $625.7+/-4.3$ & $25.79-.-4.38$ \\
\hline
\end{tabular}

Table 2. Mean and Standard Deviation of the age of the patients with respect to Disease and Treatment

The above table shows that the mean age of patients in both the treatment groups was similar, i.e. 25.6 years. The mean age of patients suffering from fibroadenoma was around 26 years, while that of patients diagnosed as fibrocystic disease was 25 years. 


\section{Nature of Pain}

\begin{tabular}{|c|c|c|c|}
\hline \multirow{2}{*}{ Groups } & \multicolumn{3}{|c|}{ Nature of Pain } \\
\cline { 2 - 4 } & Cyclical & Non-Cyclical & Total \\
\hline Cen & $39(63)$ & $23(37)$ & $62(100)$ \\
\hline EPO & $30(64)$ & $17(36)$ & $47(1000)$ \\
\hline
\end{tabular}

Table 3. Number and Percentage distribution of patients by their nature of pain with respect to Treatment

Note: Figures in brackets are in percentages.

Mastalgia patients were grouped into cyclical and noncyclical pain categories. In both the treatment groups, more than 60 percent of the patients had cyclical breast pain, defined by increase in intensity of pain before the menstrual cycle.

\section{Pain Response to Treatment}

Mastalgia was present in 63 patients in the centchroman group and 47 patients in the EPO arm. One patient in the Centchroman group developed an allergic rash soon after treatment with Centchroman and was excluded from the study. Of the remaining 62 patients of breast pain treated with Centchroman, $8(13 \%)$ patients had severe mastalgia and all of them showed an excellent response to treatment with either complete disappearance of pain or mild pain which subsided on continuation of once weekly drug therapy for another 3 months of treatment. In comparison of the $3(6 \%)$ patients with severe breast pain interfering with the patient's ability to work, none had significant pain reduction after 3 months of EPO therapy.

\begin{tabular}{|c|c|c|c|c|c|}
\hline \multirow{4}{*}{ Group } & \multicolumn{4}{|c|}{$\begin{array}{c}\text { Response to Treatment } \\
\text { (Cardiff Breast Pain Score) }\end{array}$} & \multirow{2}{*}{ Total } \\
\cline { 2 - 5 } & $\begin{array}{c}\text { Excellent } \\
\text { Responstantial }\end{array}$ & $\begin{array}{c}\text { Poor } \\
\text { Response }\end{array}$ & $\begin{array}{c}\text { No } \\
\text { Response }\end{array}$ & Response & \\
\hline Cen & $52(84)$ & $10(16)$ & 0 & 0 & $62(100)$ \\
\hline EPO & $12(25)$ & $25(54)$ & $8(17)$ & $2(4)$ & $47(100)$ \\
\hline
\end{tabular}

Table 4. Number and Percentage distribution of patients by their pain response measured as Cardiff Breast Pain Score with respect to Disease and Treatment

Note: Figures in brackets are in percentages.

62 patients in the Centchroman group were treated for mastalgia over 3 months. Of these, $84 \%$ showed an excellent response to pain as recorded by the Cardiff breast pain score after 3 months of treatment. In the EPO group, however, only $25 \%$ of a total of 47 mastalgia patients showed an excellent pain response after treatment.

\begin{tabular}{|c|c|c|c|}
\hline $\begin{array}{c}\text { Response to } \\
\text { Treatment }\end{array}$ & \multicolumn{3}{|c|}{ Groups } \\
\cline { 2 - 4 } Centchroman & EP0 & \\
\hline With pain & $10(16)$ & $35(74.5)$ & $\begin{array}{c}\text { P value } \\
<0.0001\end{array}$ \\
\hline Without pain & $52(84)$ & $12(25.5)$ & $\begin{array}{c}\text { P value } \\
<0.0001\end{array}$ \\
\hline Total & $\mathbf{6 2}(100)$ & $\mathbf{4 7}(100)$ & \\
\hline $\begin{array}{c}\text { Table 5. Number and Percentage distribution of patients } \\
\text { with complete and incomplete response to pain with } \\
\text { respect to Treatment Groups }\end{array}$ \\
\hline
\end{tabular}

Note: Figures in brackets are in percentages.
A total $52(84 \%)$ of the 62 patients with mastalgia were pain free after 3 months of Centchroman treatment, while only $12(25 \%)$ of those in the EPO group were without pain after treatment. This difference in pain response was statistically significant.

\section{Response of Tender Nodularity}

\begin{tabular}{|c|c|c|c|}
\hline \multirow{2}{*}{ Groups } & \multicolumn{2}{|c|}{$\begin{array}{c}\text { Number of Patients (\% Age of } \\
\text { Mastalgia Patients) }\end{array}$} & \multirow{2}{*}{$\begin{array}{c}\text { \% Age } \\
\text { Reduction }\end{array}$} \\
\cline { 2 - 3 } & $\begin{array}{c}\text { Pre- } \\
\text { Treatment }\end{array}$ & Post-Treatment & \\
\hline Cen & $34(55)$ & $7(11.3)$ & 80 \\
\hline EPO & $23(49)$ & $17(36)$ & 26 \\
\hline
\end{tabular}

Table 6. Response of Nodularity with respect to Treatment Groups

Note: Figures in brackets are in percentages.

Some patients had tender nodularity along with pain in one or both breasts. There was $80 \%$ remission in tender nodularity in the Centchroman Group after 3 months of treatment, while only $26 \%$ of patients in the EPO group with nodularity had any response to treatment.

\section{Fibroadenoma: Quadrant of Involvement}

\begin{tabular}{|c|c|c|c|c|c|c|}
\hline \multirow{2}{*}{ Groups } & \multicolumn{5}{|c|}{ Quadrant } & \multirow{2}{*}{ Total } \\
\cline { 2 - 6 } & $\begin{array}{c}\text { Upper } \\
\text { Lateral }\end{array}$ & $\begin{array}{c}\text { Lower } \\
\text { Lateral }\end{array}$ & $\begin{array}{c}\text { Lower } \\
\text { Medial }\end{array}$ & $\begin{array}{c}\text { Upper } \\
\text { Medial }\end{array}$ & Central & \\
\hline Cen & $15(60)$ & $\begin{array}{c}6 \\
(24)\end{array}$ & $2(8)$ & $2(8)$ & 0 & $\begin{array}{c}25 \\
(100)\end{array}$ \\
\hline EPO & $\begin{array}{c}10 \\
(58.9)\end{array}$ & $\begin{array}{c}4 \\
(23.5)\end{array}$ & $\begin{array}{c}3 \\
(17.6)\end{array}$ & 0 & 0 & $\begin{array}{c}17 \\
(100)\end{array}$ \\
\hline
\end{tabular}

Table 7. Number and Percentage distribution of patients of Fibroadenoma according to quadrant of involvement with respect to Treatment

Note: Figures in brackets are in percentages.

The upper outer quadrant was the most frequent location of fibroadenoma in both EPO and Centchroman groups.

\section{Pre-Treatment Lump Size}

\begin{tabular}{|c|c|c|c|c|c|}
\hline \multirow{2}{*}{ Groups } & \multicolumn{4}{|c|}{ Pre-Treatment } & \multirow{2}{*}{ Total } \\
\cline { 2 - 5 } & $\mathbf{0}$ - 1 & $\mathbf{1 . 1} \mathbf{- 2 . 0}$ & $\mathbf{2 . 1} \mathbf{- 3}$ & $\mathbf{3} \mathbf{- 4}$ & \\
\hline Cen & $3(12)$ & $5(12)$ & $13(52)$ & $4(16)$ & $25(100)$ \\
\hline EPO & $4(23.5)$ & $6(35.3)$ & $5(29.4)$ & $2(11.8)$ & $17(100)$ \\
\hline
\end{tabular}

Table 8. Number and Percentage distribution of patients by their pre-treatment lump size (in $\mathrm{cm}$ ) with respect to Disease and Treatment

Note: Figures in brackets are in percentages.

The mean pre-treatment lump size of fibroadenoma patients in the Centchroman group was $2.31 \mathrm{~cm}$, while that in the EPO group was $1.7 \mathrm{~cm}$. 
7. Fibroadenoma Response to Treatment

\begin{tabular}{|c|c|c|c|c|}
\hline \multirow{2}{*}{ Group } & \multicolumn{3}{|c|}{ Response to Treatment } & \multirow{2}{*}{ Total } \\
\cline { 2 - 4 } & $\begin{array}{c}\text { No } \\
\text { Response }\end{array}$ & $\begin{array}{c}\text { Partial } \\
\text { Response }\end{array}$ & $\begin{array}{c}\text { Complete } \\
\text { Response }\end{array}$ & \\
\hline Centchroman & $6(24)$ & $8(32)$ & $11(44)$ & $25(100)$ \\
\hline EPO & $12(71)$ & $4(23)$ & $1(6)$ & $17(100)$ \\
\hline Table 9. Number and Percentage distribution of \\
Fibroadenoma patients according \\
to response with respect to Treatment
\end{tabular}

Note: Figures in brackets are in percentages.

Patients in the fibroadenoma group were monitored for lump size after 1 month and 3 months of treatment. There was a mean reduction of $1.2 \mathrm{~cm}$ in lump size in the centchroman arm. Patients were further grouped into 3 response categories: Complete regression, partial regression and no response. $44 \%$ of the patients, i.e. 11 out of 25 lumps showed complete disappearance after 3 months of treatment in the centchroman group. In comparison, only 6 persons of the fibroadenomas in the EPO group showed complete regression. 12 out of 17 lumps, i.e. $71 \%$ of fibroadenomas in the EPO group did not respond to 3 months of therapy, whereas only $24 \%$ of the patients in the centchroman group with fibroadenomas did not respond to therapy.

\begin{tabular}{|c|c|c|c|}
\hline \multirow{2}{*}{ Group } & $\begin{array}{c}\text { Percentage of Reduction of } \\
\text { Lump Size }\end{array}$ & \multirow{2}{*}{ Total } \\
\cline { 2 - 3 } & $>=50$ & $<50$ & \\
\hline Centchroman & $12(48)$ & $13(52)$ & 25 \\
\hline Primrose Oil & $1(6)$ & $16(94)$ & 17 \\
\hline $\begin{array}{c}\text { Table 10. Test of Significance of the two medicines based } \\
\text { on the outcome for Fibroadenoma (F2) in terms of } \\
\text { reduction in the size of the Lump }\end{array}$ \\
\hline
\end{tabular}

Note: Figures in brackets are in percentages.

The odds ratio for the above table is 14.46 , i.e. the odds that centchroman will cause a $>50 \%$ reduction in the lump size is 14 times higher than that of EPO.

\section{Adverse Effects \\ EPO Group \\ Nil.}

\section{Centchroman Group}

- Delay in menstruation- $5(6 \%)$

- $\quad$ Scanty menses- $2(2.4 \%)$

- $\quad$ Rash- I (1.2\%)

\section{DISCUSSION}

Benign Breast Disease (BBD) is frequent in premenopausal female patients. The commonly used drugs for treatment include Evening Primrose Oil (EPO), Danazol, Bromocriptine and Tamoxifen. In an effort to treat mastalgia and fibroadenomas, we tried Centchroman, a novel non-steroidal anti-oestrogen that is marketed in India as an antiimplantation agent for contraceptive use.

Of the 140 patients of non-high-risk group of benign breast disease analysed in our study, 100 (71) were suffering from fibrocystic breast disease and 40 (29\%) had fibroadenomas. Of the 100 patients of fibrocystic breast disease, 59 were treated with Centchroman and 41 with Evening Primrose Oil (EPO). 23 of the 40 patients of fibroadenomas were given Centchroman and 17 treated with primrose oil. In the Centchroman group 63 patients had mastalgia, while in the EPO group the number was 47.4 $(17 \%)$ of the fibroadenoma patients in the Centchroman group had pain as well, while $6(35 \%)$ of those in the EPO group had pain too. In our study, we found that Fibrocystic Breast Disease (FBD) was the most common type of benign breast disease. Greenberg and Associates reported rates of occurrence of fibroadenomas at 7 to $13 \%$ in women attending breast clinics. ${ }^{39}$ The mean age of patients in both the treatment groups was approximately the same, i.e. around 25.6 years. The mean age of patients suffering from both fibroadenoma and fibrocystic disease overall was also the same. This was in contrast to some authors who report a peak incidence rate of fibroadenomas at 20 years of age. ${ }^{29}$ Regarding the nature of breast pain, cyclical mastalgia was more common in both the treatment groups. In the Centchroman group it comprised of $39(63 \%)$ patients, while in the EPO group it comprised of $30(64 \%)$ patients. This is in accordance with studies that report that cyclical breast pain is more common. ${ }^{38}$ However, in contrast to observations that cyclical mastalgia is a premenopausal symptom experienced by women aged 30 - 50 years, ${ }^{40,41}$ our patients were remarkably younger aging around 26 years. One patient in the mastalgia group treated with Centchroman developed a rash soon after treatment was started and was excluded from the study. Coming to the patients with fibroadenomas, these lumps were most commonly seen in the upper outer quadrant in both the treatment groups. 2 of the 40 patients in the Centchroman group had two fibroadenomas each, while no such patients existed in the EPO group. Mastalgia of the 62 patients who underwent treatment with Centchroman alternate day therapy for 3 months, $13 \%$ had severe pain which interrupted their daily activities to start with while $6 \%$ of the 47 patients in the EPO group had severe mastalgia before treatment. Goyal and Mansel have reported rates of $10-20 \%$ for severe mastalgia interfering with daily activities. ${ }^{38}$

$52(82 \%)$ patients showed an excellent pain response to Centchroman treatment as measured by a reduction in Cardiff breast pain score, while the remaining $10(16 \%)$ patients had a substantial response to Centchroman. At the end of 3 months, $84 \%$ of the patients in the Centchroman arm were completely pain free. In comparison, only 12 (25\%) patients receiving EPO showed an excellent response to 3 months therapy; $21 \%$ patients showing poor or no response, and the remaining $54 \%$ patients showing partial pain response. Thus, at the end of 3 months, a whopping $75 \%$ of the patients in the EPO arm with mastalgia still had some degree of pain, only $25 \%$ being completely pain free. All of the patients who had severe mastalgia to start within the Centchroman arm responded completely to treatment, while none of the patients with severe pain in the EPO group were pain free after therapy. This difference in pain response was statistically significant. Comparing our findings to the pilot study conducted by Dhar and Srivastava in AIIMS,31 their study reported an almost complete response of mastalgia with a decrease in VAS scoring from 10 to 3 in $90 \%$ of the patients. 
We had 23 patients with fibroadenomas in the Centchroman group and 17 patients in the EPO group to start with. The mean lump size in the Centchroman group was $2.31 \mathrm{~cm}$ and that in the EPO group was $1.7 \mathrm{~cm}$ to start with. After 3 months of treatment $44 \%$ of the patients in centchroman group showed complete disappearance of lumps, while only $1(6 \%)$ patient in the EPO group had complete resolution of fibroadenoma. 32\% fibroadenomas regressed partially with centchroman, while $23 \%$ lumps in the EPO group showed partial response. Overall, $76 \%$ lumps in Centchroman group responded to therapy, while only $29 \%$ lumps in the EPO group became smaller with therapy. 24\% of lumps in centchroman group and $71 \%$ lumps in the EPO group did not respond to treatment at all. When we compared the odds of centchroman causing a more than $50 \%$ reduction in lump size as compared to EPO, the odds ratio was 14.4. This finding meant that Centchroman cases had more effective reduction in lump size of fibroadenomas as compared to EPO. The AIIMS study ${ }^{31}$ also reported a mixed response in the fibroadenoma group with centchroman: $40 \%$ showing complete disappearance, $20 \%$ lumps showing partial regression, and no response in $40 \%$ cases of fibroadenoma.

\section{CONCLUSION}

Most patients with benign breast disease are present in the third decade of life. No significant difference in age is noted in relation to the type of benign breast disease. The most common symptom in patients with benign breast disease is mastalgia and about 1 in 10 patients have pain severe enough to hamper their daily activities. Tender nodularity of one or both breasts or painless lump may also be the presenting features. The most common quadrant of affection of fibroadenomas is the upper lateral quadrant (60\%) followed by lower lateral, lower medial and upper medial and central quadrant in descending order. Centchroman is significantly better than Evening Primrose Oil (EPO) in causing regression of breast lumps in fibroadenomas. Centchroman is significantly better than EPO in causing relief from breast pain in benign breast disease. Centchroman is significantly better than EPO in regression of tender nodularity in patients of fibrocystic disease of the breast. Both Centchroman and EPO have excellent safety and side effect profile with no serious adverse effects reported in either of the treatment groups.

\section{REFERENCES}

[1] Cole P, Elwood MJ, Kaplan SD. Incidence rates and risk factors of benign breast neoplasms. Am J Epidemiol 1978;108(2):112-20.

[2] Preece PE, Mansel RE, Hughes LE. Mastalgia: psychoneurosis or organic disease? $\mathrm{Br}$ Med J 1978;1(6104):29-30.

[3] Preece PE, Mansel RE, Bolton PM, et al. Clinical syndromes of mastalgia. Lancet 1976;2(7987):670-3.

[4] Preece RE, Richard AR, Owen GM, et al. Mastalgia and total body water. Br Med J 1975;4(5995):498-500.

[5] Cole EN, Sellwood RA, England PC, et al. Serum prolactin concentrations on benign breast disease throughout the menstrual cycle. Eur J Cancer 1977;13(6):597-603.
[6] Kumar S, Mansel RE, Hughes LE, et al. Prolactin response to thyrotropin-releasing hormone stimulation and dopaminergic inhibition in benign breast disease. Cancer 1984;53(6):1311-5.

[7] Khanna AK, Tapodar JK, Khanna HD, et al. Behaviour of estrogen receptor, histologic correlation and clinical outcome in patients with benign breast disorders. Eur J Surg 2002;168(11):631-4.

[8] Gateley CA, Maddox PR, Pritchard GA, et al. Plasma fatty acid profiles in benign breast disorders. Br J Surg 1922;79(5):407-9.

[9] Sharma AK, Mishra SK, Salila M, et al. Cyclical mastalgia-Is it a manifestation of an aberration in lipid metabolism? Indian J Physiol Pharmacol 1994;38(4):267-71.

[10] Fentiman IS, Caleffi M, Hamed H, et al. Dosage and duration of tamoxifen for mastalgia: a controlled trial. Br J Surg 1988;75(9):845-6.

[11] Boyd NF, Maguire V, Shannon P, et al. A clinical trial of low fat carbohydrate diet in patients with cyclical mastalgia. Breast Cancer Res and Treat 1987;10:117.

[12] Ernster VL, Mason L, Goodson WH 3rd, et al. Effects of caffeine free diet on benign breast disease: a randomized trial. Surgery 1982;91(3):263-7.

[13] Minton JP, Foeking MF, Webster DJ, et al. Response of fibrocystic disease to caffeine withdrawal and correlation with cyclic nucleotides with breast disease. Am J Obstet Gynecol 1979;135(1):157-8.

[14] Ory H, Cole P, MacMahon B. Oral contraceptives and reduced risk of benign breast diseases. $\mathrm{N}$ Eng J Med 1976;294:419-22.

[15] Colak T, Ipek T, Kanik A, et al. Effect of topical NSAIDs in mastalgia treatment. Am Coll Surg 2003;196(4):525-30.

[16] Pashby NL, Mansel RE, Hughes LE, et al. A clinical trial of evening primrose oil in mastalgia. Br J Surg 1981;68:801-24.

[17] Greenblatt RB, Dmowski WP, Mahesh VB, et al. Clinical studies with an Antigonadotrophin-Danazol. Fertil Steril 1971;22(2):102-12.

[18] Hinton CP, Bishop HM, Holliday HW, et al. A double blind controlled trial of danazol and bromocriptine in the management of severe cyclical breast pain. $\mathrm{Br} \mathrm{J}$ Clin Pract 1986;40(8):326-30.

[19] Blichert-Toft M, Anderson AN, Henriksen OB, et al. Treatment of mastalgia with bromocriptine: a double blind cross-over study. Br med J 1979;1(6158):237.

[20] Mansel RE, Preece RE, Hughes LE. A double blind trial of prolactin inhibitor bromocriptine in painful breast disease. Br J Surg 1978;65(10):724-7.

[21] Fentiman IS, Brame K, Caleffi M, et al. Double-blind controlled trial of tamoxifen therapy for mastalgia. Lancet 1986;327(8476):287-8.

[22] Mansel RE, Goyal A, Preece P. European randomized multicenter study of goserelin (Zoladex) in the management of mastalgia. Am J Obstet Gnecol 2004;191(6):1942-9.

[23] Lawrence WB, Valerie PJ. Diagnosis of diseases of the breast. $1^{\text {st }}$ edn. Philadelphia: WB Saunders Company, 1997: p. 385.

[24] Dent DM, Cant PJ. Fibroadenoma. World J Surg 1989;13(6):706-10. 
[25] Viviani RS, Gebrim LH, Baracat EC, et al. Evaluation of ultrasonographic volume of breast fibroadenomas in women treated with tamoxifen. Minerva Gynecol 2002;54(6):531-5.

[26] Kambhoj VP, Ray S, Dhawan BN. Centchroman. Drugs Today 1992;28:227-32.

[27] Kamboj VP, Kar AB, Ray S, et al. Antifertility activity of 3, 4-trans-2, 2-dimethy-3-pheny1-4-p (betapyrrolidinoethoxy)-pheny 1-7-ethoxychroman. Indian J Exp Biol 1971;9:103-4.

[28] Kambhoj VP, Singh MM, Kar AB. Effect of some nonsteroidal antifertility agents on the biochemistry of the uterus and uterine fluids in rats. Indian J Exp Biol 1973;11(6):479-83.

[29] Kambhoj VP, Shetty BS, Chandra H, et al. Biological profile of centchroman - a new post coital contraceptive. Indian J Exp Biol 1977;15(12):1144-50.

[30] Datta JK, Roy S. Effect of centchroman on morphological and biochemical changes induced by testosterone propionate in uterus of rats. Indian J Exp Biol 1979;17(10):1061-3.

[31] Dhar A, Srivastava A. Role of centchroman in regression of mastalgia and fibroadenoma. World J Surg 2007;31(6):1178-84.

[32] Blommers J, de Lange-De Klerk ES, Kuik DJ, et al. Evening primrose oil and fish oil for severe chronic mastalgia: a randomized, double-blind controlled trial. Am J Obstet Gynecol 2002;187(5):1389-94.
[33] Singh MM. Centchroman, a SERM, as a contraceptive and for the management of hormone-related clinical disorders. Med Res Rev 2001;21(4):302-47.

[34] Dwivedi A, Basu R, Chuwdhutry SR, et al. Modulation of estrogenation during reimplantation period and in immature estradiol primed rat uterus by antiimplantation agent ormeloxifene. Contraception 2005;71(6):458-64.

[35] Sitruk-Ware R, Sterkers N, Mauvais-Jarvis P. Benign breast disease l: hormonal investigation. Obstet Gynecol 1974;53(4):457-60.

[36] Swain MC, Hayward JL, Bulbrook RD. Plasma oestradiol and progesterone in benign breast disease. Eur J Cancer 1973;9(8):553-6.

[37] Hadi MS. Sports brassiere: Is it a solution for mastalgia? Breast J 2000;6(6):407-9.

[38] Barros AC, Mottola J, Ruiz CA, et al. Reassurance in the treatment of mastalgia. Breast J 1999;5(3):162-5.

[39] Hughes LE, Mansel RE, Webster DJT. Benign disorders and diseases of the breast: concepts and clinical management. $2^{\text {nd }}$ edn. London: WB Saunders Company, 2000: p. 95-121.

[40] Dent DM, Hacking EA, Wilkie W. Benign breast disease: clinical classification and disease distribution. Br J Clin Pract 1988;42(Suppl):69-71.

[41] Roberts MM, Elton RA, Robinson SE, et al. Consultations for breast disease in general practice and hospital referral patterns. $\mathrm{Br} \quad \mathrm{J}$ Surg 1987;74(11):1020-2. 